\title{
REVIEW OF VINCENT CHETAIL, INTERNATIONAL MIGRATION LAW (OXFORD UNIVERSITY PRESS, 2019)
}

\section{Alan Desmond*}

International migration law is the "set of international rules and principles governing the movement of persons between states and the legal status of migrants within host countries" (p. 7), which provides a migrant-centred holistic frame of analysis (p. 8). In International Migration Law, one of the discipline's luminaries, Vincent Chetail, provides a comprehensive account of this specific set of international rules which is as eminently readable, deeply researched and prodigiously referenced as those familiar with his work have come to expect.

Following a brief but thoughtful and wide-ranging introduction, the first chapter, logically enough, deals with the history of international migration law with the second chapter detailing the founding principles of this branch of international law. The next three chapters each address a specific category of international migrant, namely, refugees, migrant workers, and trafficked and smuggled migrants. These chapters involve a close analysis of the treaty regimes regulating the movement of people across international borders. The final two substantive chapters address the evolving role of soft law in global migration governance and contain important and timely discussion of the roles and functions of IOM and UNHCR.

While available space constraints preclude detailed discussion of each individual chapter, some of the book's elements must be highlighted. Chetail is to be commended for the lengthy and in-depth analysis conducted in respect of the UN Migrant Workers Convention in chapter 4, on migrant workers. The chapter opens with the observation that migrant workers constitute the largest portion of international migrants. Converse-

University of Leicester, alan.desmond@leicester.ac.uk 
ly, the UN Migrant Workers Convention, one of the core international human rights instruments, has been described as the best kept secret in the UN and has been blighted by a debilitating lack of endorsement from states and a concomitant academic neglect. The 31 pages of chapter 4 dedicated to this human rights treaty go some way to redressing such neglect.

Chetail rehearses in detail the many reasons advanced in explanation of the failure of states in the Global North to ratify the Migrant Workers Convention but his identification of the "decisive reason" as being Western states' reluctance to recognise migrant workers as a vulnerable group entitled to a specific form of protection (p. 245) is open to question. No mention is made of the fact that there is relatively little political capital to be made by politicians who are seen to be keen to promote the protection of migrants' rights. It is arguably this disincentive which lies at the root of political aversion to ratification, something the author to all intents and purposes recognises elsewhere in the book (p. 400).

Non-ratification in the Global North is not, however, fatal. While the 55 states which have so far ratified the Convention are largely to be found in the Global South, Chetail astutely observes that in 2015 SouthSouth migration exceeded South-North migration (p. 239), thereby highlighting the value of the Convention. Similarly, with the effortless insight which is typical of the work under review, Chetail draws attention to the way in which the Convention may be deployed to the benefit of forced migrants who have not yet qualified, or fail to qualify, as refugees under the 1951 Refugee Convention (pp. 224-227).

Some of the most interesting content is to be found in the book's final six pages in which the author presents his concluding thoughts on the future of international migration law. The chief challenges identified to effective application of international migration law are, at the normative level, states' poor track record of implementation of the relevant international rules and, at the institutional level, the difficulty inherent in efficiently managing "the complex and heteroclite array of nested institutions" (p. 399) involved in international migration governance. As a partial answer to the latter difficulty, Chetail proposes a reform of the funding system of IOM and UNHCR and, more ambitiously, a more coherent division of labour between the two with IOM assuming responsibility for international migration and UNHCR focusing on internal displacement. 
While such a radical re-structuring might make sense on paper, Chetail concedes that it is politically unfeasible.

In relation to possible future developments, Chetail identifies the capacity-building potential of the UN system to ensure states' implementation of international law, the deployment of international criminal law to tackle large-scale abuses, as well as the untapped potential of existing international migration law mechanisms such as complaint procedures under general human rights treaties, and diplomatic protection. The author highlights the recently adopted Global Compact for Migration as, inter alia, providing a robust and balanced framework for the development of the international agenda on labour migration. Failure to bring this potential to fruition "will be remembered as yet another missed opportunity in the long and turbulent history of migration" (p. 403).

Every book, however impressive, leaves room for improvement. One might have expected, for example, the topic of nationality and citizenship, so intimately connected to the phenomenon of international migration, to have been addressed. Similarly, despite the deficiency of scholarly analysis of the UN Migrant Workers Convention mentioned above, there is no reference to some of the more recent academic work concerning this human rights instrument. Such quibbles, however, in no way eclipse the impressive feat of scholarship represented by International Migration Law which achieves far more than its author's stated chief objective of demonstrating what current international migration law is and how it operates (p. 12). The book has the rare attribute of being all things to all people. For undergraduate and postgraduate students it provides an accessible and authoritative introduction to international migration law; for the policymaker, practitioner and migration law expert it represents a cornucopia of essential information, insightful observations and thought-provoking propositions. It is an indispensable addition to the bookshelf of anyone concerned with international migration. 
